九州大学学術情報リポジトリ

Kyushu University Institutional Repository

\title{
Phytotoxin Produced by Pseudomonas glumue Kurita et Tabei, a Causal Bacterium of the Grain and Seedling Rot of Rice
}

I i yama, Kazuhiro

Laboratory of Plant Pathology, Faculty of Agriculture, Kyushu University

Furuya, Naruto

Laboratory of Plant Pathology, Faculty of Agriculture, Kyushu University

Hara, Kohyu

Laboratory of Plant Pathology, Faculty of Agriculture, Kyushu University

Nakashima, Nobuhiko

Laboratory of Plant Pathology, Faculty of Agriculture, Kyushu University

他

https://doi.org/10.5109/24049

出版情報 : 九州大学大学院農学研究院紀要. 38 (3/4)，pp. 175-181，1994-03. Kyushu University バージョン：

権利関係 : 


\title{
Phytotoxin Produced by Pseudomonas glumae K urita et Tabei, a Causal Bacterium of the Grain and Seedling $R$ ot of $R$ ice
}

\author{
K azuhiro liyama, $\mathrm{N}$ aruto $\mathrm{F}$ uruya, K ohyu $\mathrm{H}$ ara, N obuhiko $\mathrm{N}$ ak ashima, \\ Yoichi Takanami and Nobuaki M atsuyama
}

Laboratory of Plant Pathology, Faculty of Agriculture, Kyushu University 46-01, Fukuoka 812, Japan

(Received November 10, 1993)

\begin{abstract}
The phytotoxin produced by Pseudomonas glumae, the causal agent of bacterial grain and seedling rot of rice, was purified and characterized. The ultraviolet and visible absorption spectrum of the phytotoxin exhibited two maxima at $260 \mathrm{~nm}$ and $399 \mathrm{~nm}$ in $80 \%$ aqueous methanol. In the infrared absorption spectrum, main bands at 2,800 $3,000 \mathrm{~cm}^{-1}, 1,680 \mathrm{~cm}^{-1}, 1,540 \mathrm{~cm}^{-1}$ and $1,050 \mathrm{~cm}^{-1}$ were observed, suggesting the presence of a methyl group, a ketone group, a benzene ring and a carbon- hydrogen bond, respectively. The molecular weight of this substance was determined as 193 and the molecular formula was decided as $\mathrm{C}_{7} \mathrm{H}_{7} \mathrm{~N}_{5} \mathrm{O}_{2}$ by a high resolution EI mass spectrometry. The phytotoxin was isolated noi only from the PS broth, but also from rice seedling infected with the causal bacterium. This phytotoxin might be related to the pathogenicity of P. glumae.
\end{abstract}

\section{INTRODUCTION}

Bacterial seedling rot of rice, caused by Pseudomonas glumae Kurita et Tabei, is one of the most important diseases in Asian rice growing countries. This pathogen causes seedling rot in nursery boxes and grain rot of panicles after heading (Goto et al., 1956 and 1958; Uematsu et al., 1976a and 1976b). These symptoms are characterized by rotting of grain and seedling, and inhibition of growth with cholorosis or necrosis on leaves or leaf sheaths.

Some plant pathogenic pseudomonads are known to produce phytotoxins. Stewart (1971) showed that tabtoxin was produced by P.syringae pv. tabaci in the wildfire disease of tobacco. Mitchell (1976) reported the phaseolotoxin production by $\mathbf{P}$. syringae pv. paseolicola causing leaf - cholorosis in bean leaves, and it's purified and characterized. Lindberg et al. (1980) found the tropolone produced by Pseudomonas sp. which was bioactive to plants, fungi and bacteria (Lindberg 1981). Moreover, Sato et al. (1988) reported that P.glumae strain Pg-1 produced fluorescent pigments, toxoflavin and fervenulin causing inhibition of seedling elongation and chlorosis on detached leaves of rice in King's B medium. However, the role of these phytotoxins in the pathogenesis of P.glumae in rice seedlings is still not clear. It was found in this study that toxic compounds were also produced when P.glumae was cultured in potato semi synthetic broth at 30 " $\mathrm{C}$, thereby inhibiting growth of rice seedlings and inducing chlorosis on rice leaves (Hara et al., 1992). Furthermore, these toxic compounds were detected in rice seedlings infected with P. glumae (liyama et al., 1993). The results of purification and characterization of the phytotoxin will be contributed in this report. 


\section{MATERIALS AND METHODS}

\section{Bacterial strain}

A highly virulent strain 2 of P.glumae, kindly donated by Kyushu National Agricultural Experimental Station, was used in this study. The bacterium was grown on a potato semi -synthetic medium $\left(\mathrm{PSA} ; \mathrm{Na}_{2} \mathrm{HPO}_{4} \cdot 12 \mathrm{H}_{2} \mathrm{O} 2.0 \mathrm{~g}, \mathrm{Ca}\left(\mathrm{NO}_{3}\right)_{2} .4 \mathrm{H}_{2} \mathrm{O} 0.5 \mathrm{~g}\right.$, polypeptone $5.0 \mathrm{~g}$, sucrose $20.0 \mathrm{~g}$, agar $15.0 \mathrm{~g}$ in $1,000 \mathrm{ml}$ decoction of potato $300 \mathrm{~g}$, and the $\mathrm{pH}$ value was adjusted to 7.0 before autoclaving) at $30^{\circ} \mathrm{C}$ for $48 \mathrm{hr}$. From this plate, a single colony was selected, streaked on a PSA slant, and incubated at $30^{\circ} \mathrm{C}$ for $48 \mathrm{hr}$. The bacterium was preserved as suspension in sterile water or a lyophilized state. The suspension was kept at room temperature for routine work, while the lyophilized preparation was kept at $4^{\circ} \mathrm{C}$ for long-term preservation. As required, a loopful of the suspension was streaked on PSA plates and incubated at $30^{\circ} \mathrm{C}$ for $48 \mathrm{hr}$ for single colony subculturing.

\section{Phytotoxin extraction from rice seedlings infected with $P$.glumae}

Seeds of the rice cultivar "Asominori", surface-sterilized with sodium hypochlorite solution (active chloride 3\%), were inoculated with 1? glumae strain 2, and incubated in a growth room at $26^{\circ} \mathrm{C}$ for 10 days. Uninoculated seeds incubated under similar conditions were served as a control.

After 10 days, seedlings were homogenized with a mortar and pestle and shaken with an equal volume of chloroform. Chloroform extract concentrated by nitrogen gas blowing was subjected to analytical silicagel (Wako - gel B -10) thin - layer chromato graphy (TLC). After development with a solvent system, ethyl acetate - chloroform acetic acid $(20: 8: 1, \mathrm{v} / \mathrm{v} / \mathrm{v})$, spots were detected under UV light $(365 \mathrm{~nm})$.

\section{Phytotoxin extracted from culture filtrate and purification}

The procedure for purification is outlined in Fig. 1. A virulent strain 2 was precultured in a test tube containing $10 \mathrm{ml}$ of potato semi-synthetic broth for 1 day. Then $5 \mathrm{ml}$ of the bacterial suspension was inoculated into $200 \mathrm{ml}$ of PS broth in a Sakaguchiflask and grown at $30^{\circ} \mathrm{C}$ for 4 days on a rotary shaker (140 strokes $\left./ \mathrm{min}\right)$. After incubation, the culture filtrate was collected by centrifugation $(4,000 \mathrm{~g}, 10 \mathrm{~min})$. The culture filtrate was concentrated to one tenth of the original volume by evaporation in vacuo at less than 40 " $\mathbf{C}$, and then extracted with chloroform. The extract was chromatographed on silica gel (Wako-gel B-10) TLC by developing it with dichloromethane - methanol $(9: 1, \mathrm{v} / \mathrm{v})$. The detection under UV (365nm) was carried out immediately after the developing solvent had reached $10 \mathrm{~cm}$-line from the origin. Every detected spot was fractionated and eluted with methanol, and assayed for the phytotoxin activity. Silica gel powder of the area ( $\operatorname{Rf} 0.4-0.5)$ exhibiting dark orangecoloration was collected, and eluted with methanol to be rechromatographed on a silica gel plate with chloroform-ethanol $(9: 1, \mathrm{v} / \mathrm{v}>$. The active zone was scraped from the plate and eluted with methanol. The eluate was concentrated in vacuo, subjected to TLC with ethyl acetate-chloroform-acetic acid (20: 8:1, v/v/v >. Then, the active zone was scraped from the plate and eluted with distilled water (Katayama Chemical Co. Ltd.).

The eluate with distilled water was shaken with an equal volume of chloroform in 


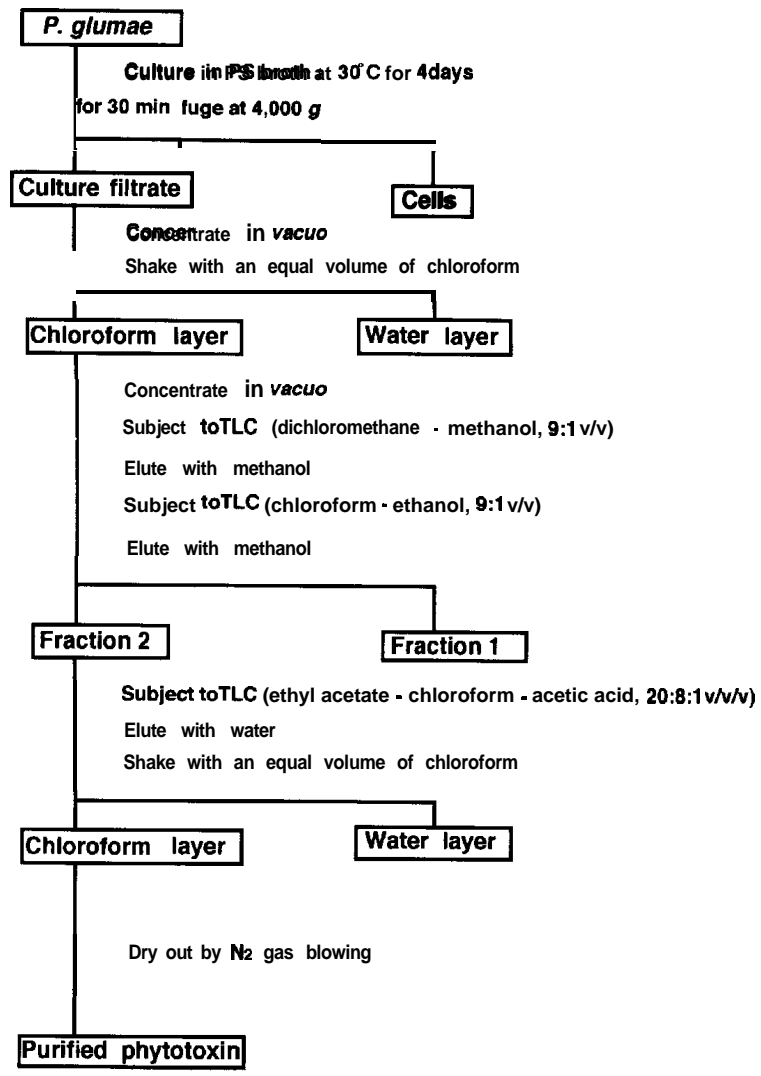

Fig. 1. Procedure for purification of the phytotoxin produced by P. glumae.

order to remove ashes. The chloroform layer was dried with an evaporator and by nitrogen gas blowing. Purity of the phytotoxin was estimated using a high performance liquid chromatography equipped with a Shodex DM614 column and a UV absorbance detector. The phytotoxin was eluted at $1 \mathrm{ml} / \mathrm{min}$ flow rate using methanol- water $(80$ : $20, \mathrm{v} / \mathrm{v})$. The wavelength for the detection of the phytotoxin was $260 \mathrm{~nm}$.

\section{Bioassay for toxicity}

Bioassay of phytotoxic activity was carried out by the method described below. Rice seeds (cv. "Asominori") were husked, surface disinfected with $70 \%$ ethanol for lmin and 3\% sodium hypochlorite solution (Antiformin) for 90min, and rinsed in sterilized distilled water. Seeds were germinated at $28^{\circ} \mathrm{C}$ for 2 days under the dark condition. Three pre-germinated seeds were incubated with $2 \mathrm{ml}$ of the test solution at $30^{\circ} \mathrm{C}$ for 14 days under continuous light condition $(34,000-40,000$ lux $)$ in a test tube. The seeds were similarly treated with sterilized distilled water as the check. Toxicity was estimated by measuring the lengths of the sprout and root of the seedlings. 


\section{Spectral analysis}

UV spectra of the phytotoxin were recorded by a Beckman DU-65 spectrophoto-m eter. IR spectrum was obtained using an Infrared Spectrophotometer A - 300 (Japan Spectroscopic Co., Ltd. Tokyo Japan) using a pellet of $\mathrm{KBr}$ disk.

EI mass spectrometry spectrum was obtained by a JEOL JMS-D300 Spectrometer (ionization voltage $30 \mathrm{eV}$ ) using a direct inlet system.

\section{Recrystallization of the phytotoxin}

For complete purification, recrystallization of the phytotoxin was conducted by adding a small volume of hexane to a chloroform solution.

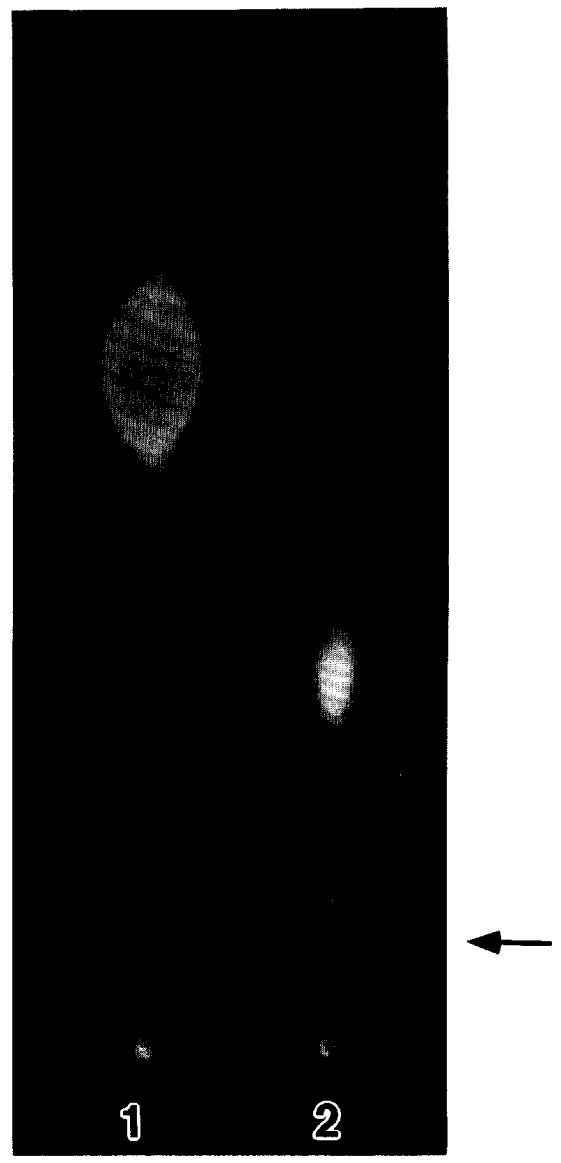

Fig. 2. TLC of chloroform extract from rice plants infected with P.glumae.

1: Healthy plant

2: Infected plant

Arrow indicates the spot of the phytotoxin.

Spots were detected by UV irradiation $(365 \mathrm{~nm})$.

Solvent: ethyl acetate-chloroform-acetic acid $(20: 8: 1, \mathrm{v} / \mathrm{v} / \mathrm{v})$

Plate: Silica gel (Wako-gel B-10) 


\section{RESULTS AND DISCUSSION}

\section{Phytotoxin extraction from rice seedlings infected with $P$.glumae}

As shown in Fig. 2, thin -layer chromatograms of chloroform extracts from seedlings infected with P.glumae and healthy control seedlings were distinctly different. A dark yellow spot appeared at Rf 0.12 in the sample from the infected plants. The behaviors of the spot in mobility and color under UV were the same with the phytotoxin extracted from the culture filtrate. This result showed that the phytotoxin was produced not only in the PS broth, but also in vivo. Moreover, the phytotoxin might be related to the pathogenicity of P.glumae.

\section{Extraction of the phytotoxin from culture filtrate}

Isolation of the phytotoxin was carried out using preparative TLC. The extract with chloroform from culture filtrate contained phytotoxins appearing around $\mathrm{Rf}$ 0.4-0.5 on the silicagel TLC with dichloromethane-methanol (9: 1, v/v). When the eluate of the corresponding area ( $\operatorname{Rf} 0.4-0.5$ ) was subjected to the preparative TLC with chloroformethanol (9: 1, v/v>, two bioactive spots were detected at $\operatorname{Rf} 0.14$ and 0.34 . The substance at Rf 0.34 was confirmed as an artifact which was denatured on the silica gel plate during TLC. The fraction at Rf 0.14 was subjected to TLC with ethyl acetate chloroform-acetic acid (20:8:1, v/v/v) and the bioactive fraction appeared at Rf 0.12 . This fraction was eluted with deionized water, and was transferred to chloroform by shaking with an equal volume of chloroform. The chloroform was evaporated and the purity of this sample was estimated by HPLC.

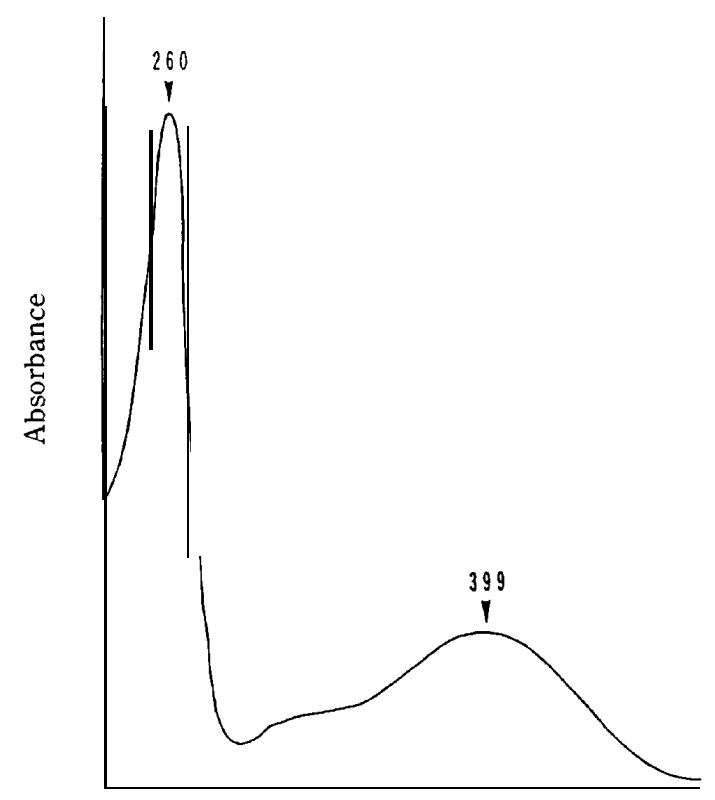

Fig. 3. Ultraviolet and visible absorption spectrum of the phytotoxin. 


\section{Spectral analysis}

As shown in Fig. 3, the ultraviolet and visible absorption spectrum of the phytotoxin exhibited two maxima at $260 \mathrm{~nm}$ and $399 \mathrm{~nm}$ in $80 \%$ methanol.

In the infrared absorption spectrum, it had main bands at $2,800-3,000 \mathrm{~cm}^{-1}, 1,680 \mathrm{~cm}^{-1}$, $1,540 \mathrm{~cm}^{-1}$ and $1,050 \mathrm{~cm}^{-1}$. These bands suggested the presence of a methyl group, a ketone group, a benzene ring and a carbon-hydrogen bond, respectively (Fig. 4).

The molecular weight of this substance was determined as 193 and the molecular formula was decided as $\mathrm{C}_{7} \mathrm{H}_{7} \mathrm{~N}_{5} \mathrm{O}_{2}$ by a high resolution EI mass spectrometry (Fig. 5).

\section{Recrystallization of the phytotoxin}

The crystal of the phytotoxin was yellow in color, and long narrow and pin pointed in shape (Fig. 6).

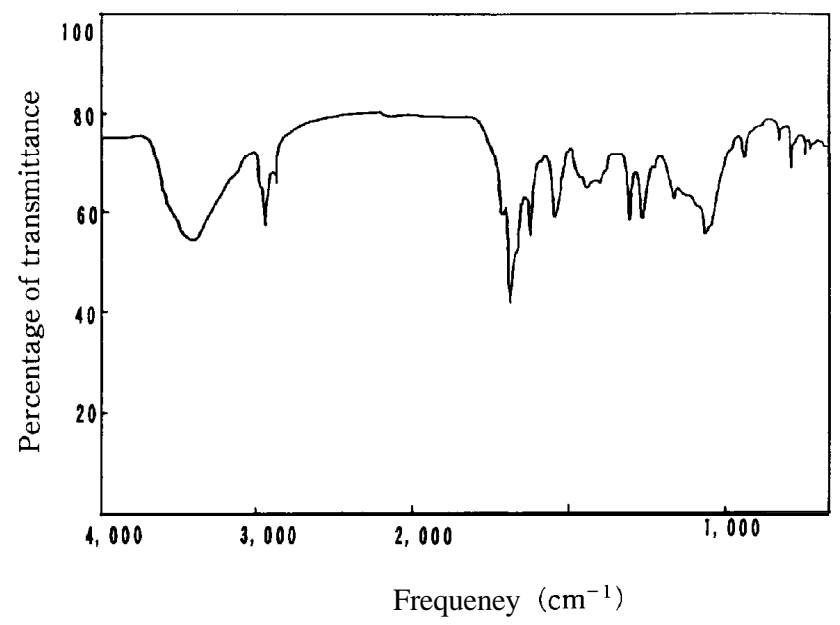

Fig. 4. Infrared spectrum of the phytotoxin in $\mathrm{KBr}$ micro disk.

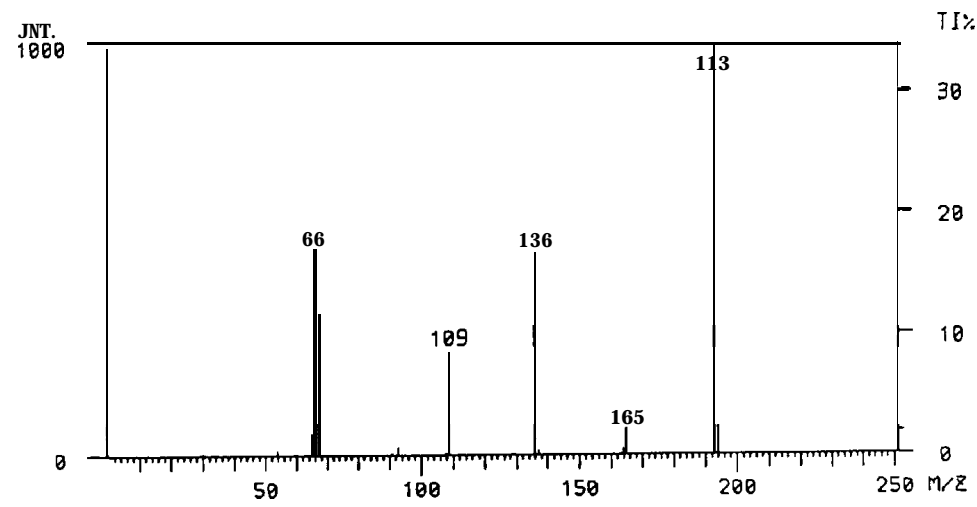

Fig. 5. EI-MS spectrum of the phytotoxin. 


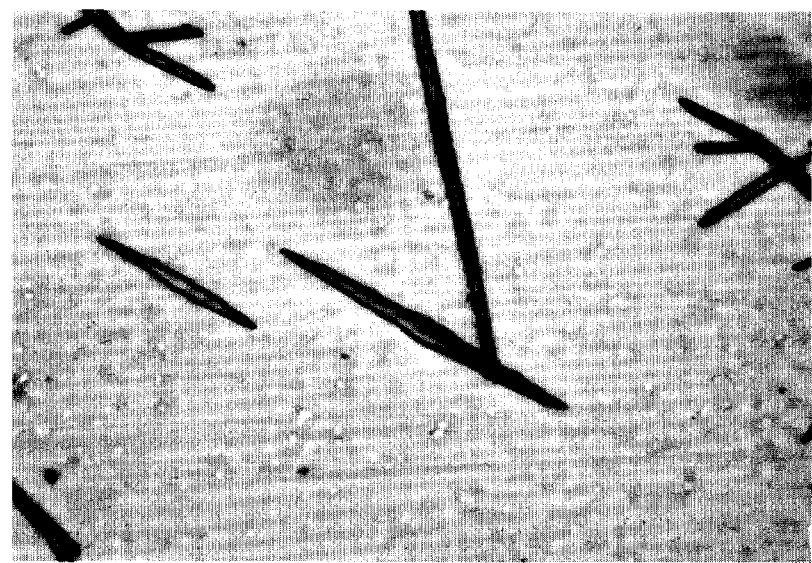

Fig. 6. Crystal of the phytotoxin produced by $P$. glumae.

\section{ACKNOWLEDGEMENT}

The authors are indebted to Dr. R. Isobe, Faculty of Pharmaceutical Sciences, Kyushu University for decision of the molecular formula of the phytotoxin produced by $P$. glumae.

\section{REFERENCES}

Goto, K. and K. Ohta 1956 New bacterial diseases on rice. Ann. Phytopath. Soc. Japan, 21: 46-47 (Abst. in Japanese)

Goto, K. and K. Ohta 1958 Bacterial grain rot of rice. Ann. Phytopath. Soc. Japan, 23: 155

Hara, K., N. Nakashima, N. Furuya, K. Koga, K. Tsuno, S. Wakimoto and N. Matsuyama 1992 Studies on the growth inhibitor of rice seedlings produced by Pseudomonas glumae Kurita et Tabei. Ann. Phytopath. Soc. Japan, 58: 598 (Abst. in Japanese)

Iiyama, K., N. Furuya, K. Hara, N. Nakashima, Y. Takanami and N. Matsuyama 1993 Relationship between pathogenicity and toxin produced by Pseudomonas glumae Kurita et Tabei. Ann. Phytopath. Soc. Japan, 59: 311 (Abst. in Japanese)

Lindberg, G. D. 1981 An antibiotic lethal to fungi. Plant Dis., 65: 680-683

Lindberg, G. D., J. M. Larkin and H. A. Whaley 1980 Production of tropolone by a Pseudomonas. J. Nat. Prod., 43: 592-594

Sato, Z., K. Koiso, S. Iwasaki, I. Matsuda and A. Shirata 1988 Toxins produced by Pseudomonas glumae. Ann. Phytopath. Soc. Japan, 55: 353-356 (in Japanese)

Stewart, W. W. 1971 Isolation and proof of structure of wildfire toxin. Nature, 229: 174-178

Mitchell, R. E. 1976 Isolation and structure of a chlorosis - inducing toxin of Pseudomonas phaseolicola. Phytochemistry, 15: 1941- 1947

Uematsu, T., D. Yoshimura, K. Nishiyama, T. Ibaragi and H. Fujiki 1976a Occurrence of bacterial seedling rot in nursery flat, caused by grain rot bacterium Pseudomonas glumae. Ann. Phytopath. Soc. Japan, 42: 310-312 (in Japanese)

Uematsu, T., D. Yoshimura, K. Nishiyama, T. Ibaragi and H. Fujiki 1976b Pathogenic bacterium causing seedling rot of rice. Ann. Phytopath. Soc. Japan, 42: 464-471 (in Japanese) 